\title{
Review of three Common Congenital Abnormalities of Kidney and their Clinical Perspective with an Elaboration on a rare case of Co-Occurrence of Horse Shoe Kidney , Unilateral Duplex Kidney And Aberrant Renal Vessel With Pelviureteric Junction Obstruction Of The Lower Moiety
}

\section{Kapil Rampal *1, Devendra Prajapati ${ }^{2}$, Meghna Sharma ${ }^{3}$.}

${ }^{* 1}$ Senior Resident surgery Deen Dayal Upadhyaya Hospital ,Hari Nagar, New Delhi, India.

${ }^{2}$ Senior Resident surgery Deen Dayal Upadhyaya Hospital ,Hari Nagar, New Delhi, India.

${ }^{3}$ M edical officer PCM S-1, CHC Kasel, Tarn Taran Punjab, India.

\section{ABSTRACT}

Horse shoe kidney, pelviureteric junction obstruction, aberrant/crossing renal vessel and duplicated collecting system as individual entities are amongst commonest of renal anomalies, however very few co-occurrences have been reported. We report case study of a 17 year old male who presented to us with all these anomalies packed in a single individual. Successful surgical intervention wasperformed in the form of open pyeloplasty and the patient had an uneventful recovery.

KEY WORDS: Horse Shoe Kidney, Double M oiety, Pelviureteric junction Obstruction, Hydronephrosis, Pyeloplasty.

Address for correspondence: Dr Kapil Rampal, Senior Resident, Department of surgery, Deen Dayal Upadhyaya Hospital, Hari Nagar, New Delhi- 110064 Telephone: 9718379366/9650109599

E-Mail: balkarankapil@gmail.com

\begin{tabular}{|c|c|c|}
\hline \multicolumn{3}{|c|}{ Online Access and Article Informtaion } \\
\hline \multirow{2}{*}{ 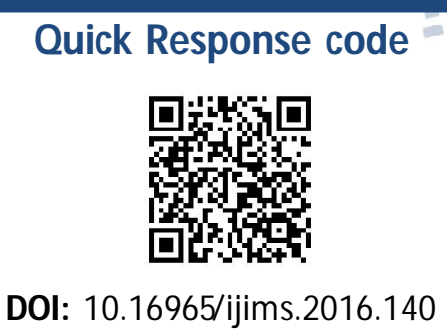 } & $\begin{array}{r}\text { International Journal } \\
\text { www.i }\end{array}$ & $\begin{array}{l}\text { egrative Medical Sciences } \\
\text { iences.com }\end{array}$ \\
\hline & $\begin{array}{l}\text { Received: 05-07-2016 med } \\
\text { Reviewed: 05-07-2016 }\end{array}$ & $\begin{array}{l}\text { Accepted: 19-07-2016 } \\
\text { Published: 31-07-2016 }\end{array}$ \\
\hline Source of Funding: Self & Con & interest: None \\
\hline
\end{tabular}

\section{BACKGROUND}

Horse shoe kidney has been reported to be the most common congenital anomaly affecting approximately 1 in 400 live births, being silent asymptomatic condition in majority [1]. In more than $90 \%$ cases the fusion happens at the inferior pole. Horseshoe kidneys have been reported in identical twins and amongst siblings. Though no hereditary traits have been discovered as yet, male is to female ratio of 2:1 is reported [2].

Embryologically the abnormality occurs between the 4th and 6 th week of gestation, after the ureteral bud has entered the renal blastema. In view of the ultimate spatial configuration of the horseshoe kidney, the entrance of the ureteral bud had to have taken place before rotation and considerably before renal ascent ensued. The pelves and ureters of the horseshoe kidney are usually anteriorly placed, crossing ventrally to the isthmus. The pelves occasionally, are anteromedial, suggesting that fusion occurred later to some rotation. The migration usually is incomplete, with the kidneys lying lower in the abdomen than normal. The inferior mesenteric, most likely artery prevents full ascent by obstructing the movement of the isthmus. In $95 \%$ of patients, the kidneys join at the lower pole; in a small number, an isthmus connects both upper poles instead. The isthmus 
is mostly bulky and consists of parenchymatous tissue with its own blood supply. The calyces, normal in number, are atypical in orientation. Because the kidney fails to rotate, the calyces point posteriorly, and the axis of each pelvis remains in the vertical or obliquely lateral plane (on a line drawn from lower to upper poles). The lowermost calyces extend caudally or even medially to drain the isthmus and may overlie the vertebral column.

The blood supply to the horseshoe kidney is variable. In $30 \%$ of cases, it consists of one renal artery to each kidney, but it may be atypical with duplicate or even triplicate renal arteries supplying one or both kidneys. The blood supply to the isthmus and lower poles is also variable. The isthmus and adjacent parenchymal masses may receive a branch from each main renal artery, or they may have their own arterial supply from the aorta originating either above or below the level of the isthmus.

Majority of horse shoe kidneys are asymptomatic but pelvi-ureteric junction obstructions are seen in around $1 / 3^{\text {rd }}$ cases. [Wein: Campbell-Walsh Urology, 9th ed.]

Duplication anomalies of collecting system are the most common upper tract anomalies with a reported incident of $0.5-0.8 \%$ in general population [3]. There appears to be a strong genetic predisposition in those with duplex kidneys. Up to $30 \%$ have relatives with compete duplex kidneys and two thirds with bifid systems. A bifid pelvis is considered as a variant of normal. Diagnosis is usually an incidental finding on ultrasound or contrast renal studies.

Pelviureteric junction obstruction is the most common cause of pediatric hydronephrosis occurring in 1 per 1000-2000 live births as variously reported having a 2 times male preponderance, with more cases now being diagnosed antenatally [4].

Etiology of Pelviureteric junction obstruction is elusive but a general consensus is for an underlying intrinsic cause. An interruption in the development of the local circular musculature or an alteration of the collagen fibers and composition between and around the muscle cells appears to be the cause. An aberrant, accessory, or early-branching lower pole vessel is the most common cause of extrinsic UPJ obstruction. These vessels pass anteriorly to the UPJ or proximal ureter and contribute to mechanical obstruction. But the causative effect of an aberrant vessel is debatable and this may just be an incidental finding. [Wein: CampbellWalsh Urology, 9th ed.]

More and more cases are being diagnosed in antenatal period. Treatment modalities included open (membered and dismembered pyeloplasty), laparoscopic, endoscopic and robotic techniques. Aim is to achieve a dependent, water tight, patent drainage system.

Despite the commonality of horse shoe kidney, duplication of collecting system or a duplex system and pelviureteric junction obstruction, co-occurrence of these in same one patient is exceedingly rare [5].

\section{CASE PRESENTATION}

A 17 year old male presented to us in surgery department with complaints of constant dull aching left flank pain with intermittent exacerbations for 02 year. No associated history of fever, haematuria, gastro-intestinal complaints or lower urinary tract symptoms present. His general and systemic examination was essentially within normal limits. All hematological and biochemical parameters were normal. The ultrasound abdomen was suggestive of bifid left kidney with severe hydronephrosis of the lower moiety. right kidney and bilateral uretrers were normal. The intravenous urogram [Figure 1] showed duplicated pelvicalyceal system of the left kidney with normal pattern in the upper moiety but the lower moiety showing gross clubbing of the calyces. Both the ureters joined opposite lumbar $3^{\text {rd }}$ and $4^{\text {th }}$ vertebrae. Left kidney was also malrotated [Figure 2]. Right kidney and bilateral ureters were normal.

CT urogram performed over the patient showed both kidneys to be fused at lower poles with isthmus infront of lumbar $3^{\text {rd }}$ vertebra, left kidney bifid with hydronephrotic lower moiety [Figure 3]. CT urogram also confirmed malrotation of left kidney with anterolaterally directed pelvis [Figure 4].

DTPA Scan showed left kidney to be bifid with a 
normally functioning upper moiety and grossly hydronephrotic but normally functioning lower moiety. Right kidney had normal functioning. The split functions obtained from DTPA scan are depicted in Table 1.

Table 1: Showing the split functions obtained from DTPA scan.

\begin{tabular}{|c|c|c|c|}
\hline & LEFT KIDNEY & RIGHT KIDNEY & TOTAL \\
\hline SPLT RENAL FUNCTION & $\begin{array}{c}48.23 \% \\
\text { UPPER M OIETY } 23.50 \% \\
\text { LOWER M 0IETY 76.50\% }\end{array}$ & $51.77 \%$ & $100 \%$ \\
\hline $\begin{array}{c}\text { GLOM ERULAR FLLTERATION } \\
\text { (m/ } / \text { min) }\end{array}$ & 48.2 & 52.8 & 100 \\
\hline
\end{tabular}

Patient planned for open pyeloplasty of the lower moiety. Per operative findings were [Figure 5 and 6] horse shoe kidney, double moiety left kidney, aberrant renal vessel crossing anterior to left lower moiety with dilated proximal part i.e. pelvis and a normal distal part i.e. ureter. Clamping of the crossing vessel resulted in ischemia of the left lower pole. Patient underwent open dismembered pyeloplasty bringing pelviureteric junction to anterior of the crossing vessel, with placement of a double J stent. The post operative period was uneventful and the stent was removed after 04 weeks.

\section{DISCUSSION}

Horse shoe kidney is a common congenital anomaly and is a resultant of many diverse teratogenic factors and can be associated with a number of metabolic disorders and Wilm's tumour. Association of horse shoe kidney with duplex collecting system that in itself is a common entity, is extremely rare. Christoffersen and his fellows have brought out that this combination is a rare occurrence [6]. Identical views were expressed by Kuzel and his colleagues who described a case of horse shoe kidney with bilateral duplicated collecting system [7]. Pode and his fellows described a case of unilateral triplification of collecting system in a horse shoe kidney [8]. Vipin Tyagi and his associates reported complete unilateral duplication of ureter with horse shoe kidney in 2013 [9]. Pelviureteric junction obstruction in majority has been attributed to abnormal intrinsic musculature [10]. Inferior aberrant vessel has been found to cross pelviureteric junction in $6.8 \%$ population. But the incidence of aberrant crossing vessel causing pelviureteric junction obstruction in a fusion anomaly has been placed at a higher level of $25 \%$ [11].

Fig. 1: Duplicated left pelvi calyceal system.

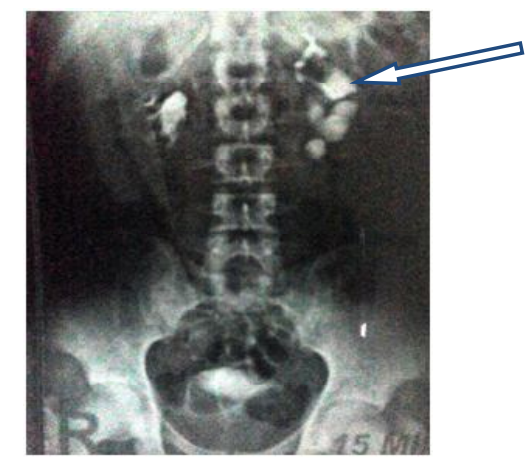

Fig. 2: Bifid ureters joing at L3-L4].

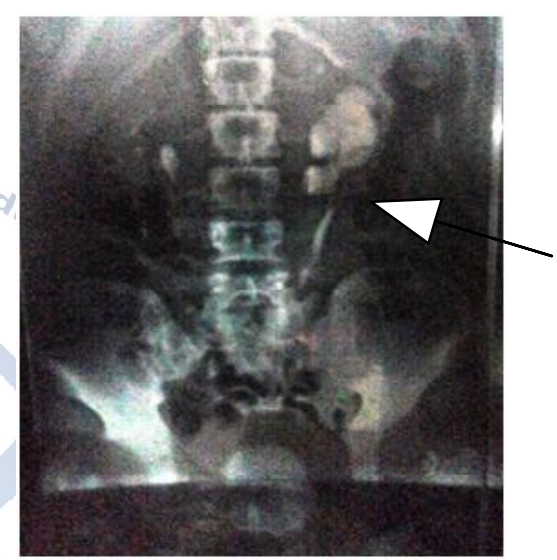

Fig. 3: Showing isthmus at $L 3$ marked with arrow

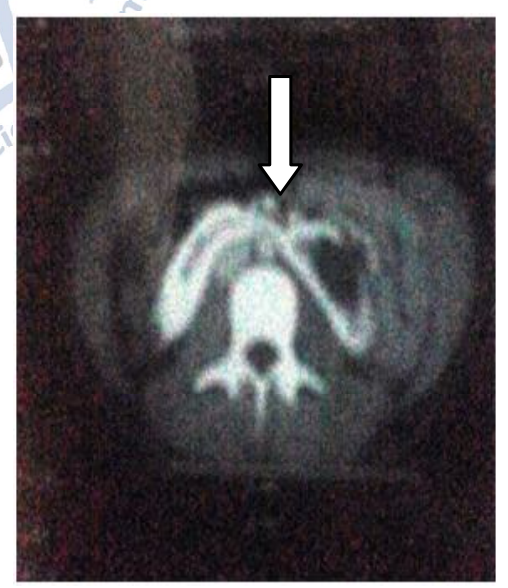

Fig. 4: Showing hydronephrotic malrotated left kidney marked with arrow

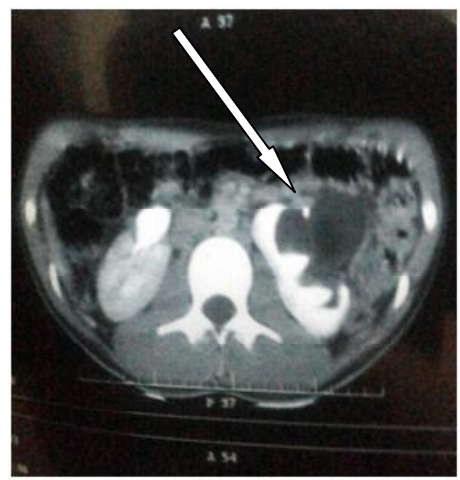


Fig. 5: Showing left kidney (blue arrow), hydronephrotic left pelvis (purple arrow), aberrant crossing vessel (green arrow)

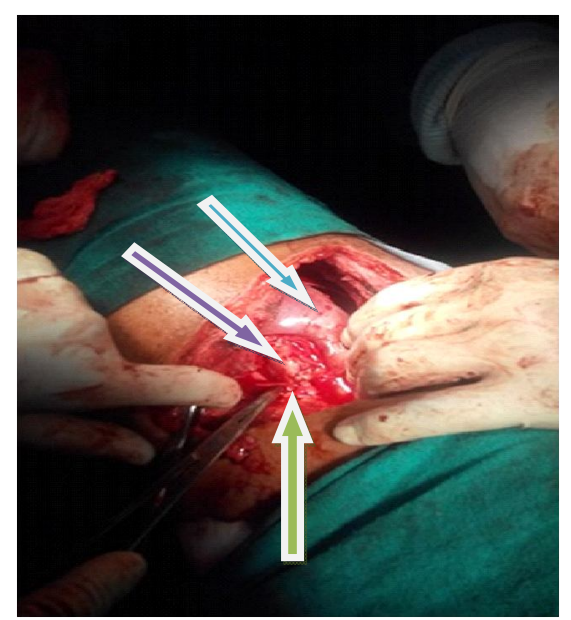

Fig. 6: hooked aberrant crossing vessel(blue arrow) and bifid ureters taped separately(green arrow) with ureters being seen joining distally(black arrow).

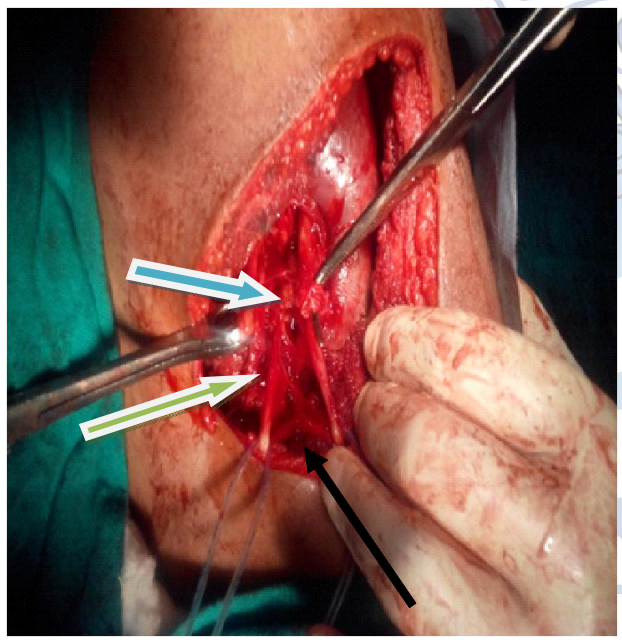

\section{CONCLUSION}

Only a few cases have been reported describing co-occurrence of horse shoe kidney with a duplicated collecting system. Our case of horse shoe kidney with double moiety with pelviureteric junction obstruction with an aberrant renal vessel thus makes it a rarest amongst the rare. We aimed for a widely patent, tension free, funnel shaped pelviureteric transition with a dependent drainage through open dismembered pyeloplasty. The patient recovered well and is asymptomatic on 06 months follow up.

\section{REFERENCES}

[1]. Bauer, S.B. (2007) Anomalies of the upper urinary tract. In Campbell-Walsh Urology. 9th ed. Wein, A.J., Kavoussi, L.R., Novick, A.C., Partin, A.W., and Peters, C.A., Eds. Saunders Elsevier, Philadelphia. p. 3283.

[2]. Glodny B, Petersen J, Hofmann KJ, et al. kidney fusion anomalies revisited: clinical and radiological analysis of 209 cases of crossed fused ectopia and horseshoe kidney. BJU Int. 2009;103:224-35.

[3]. Keskin S, Erdogan N, Kurt A, Tan S, Ipek A. Bilateral partial ureteral duplication with double collecting system in horseshoe kidney. Adv Med Sci. 2009;54:302-304.

[4]. Capello SA, Kogan BA, Giorgi LJ Jr, Kaufman RP Jr. Prenatal ultrasound has led to earlier detection and repair of ureteropelvic junction obstruction. J Urol 2005;174:1425-8.

[5]. Mirzazadeh and Richards. Duplicated Ureter in Horseshoe Kidney. TheScientificWorldJOURNAL. 2011;11:1591-1596.

[6]. Christoffersen J, Iversen HG. Partial hydronephrosis in a patient with horseshoe kidney and bilateral duplication of the pelvis and ureter. Scand J Urol Nephrol. 1976;10:91-93.

[7]. Kuzel M, Makarewicz J, M usial S, Sarzynska M. Case of horseshoe kidney with bilateral double pelvis system and double ureters (in Polish). Pediatr Pol. 1979;54:407-9.

[8]. Pode D, Shapiro A, Lebensart P. Unilateral triplication of the collecting system in a horseshoe kidney. J Urol.1983;130:533-4.

[9]. Vipin Tyagi, Tanveer Iqbal Dar, Abdul Rouf Khawaja, Sudhir Chadha. Horseshoe Kidney with Complete Unilateral Duplication of Ureter and Pelvicalyceal System. Urology burnal. Autumn 2013; 10: 11621164.

[10]. Williams, P.L., L.H. Bannister, M .M. Berry, P. Collins, M. Dyson, J.E. Dussek, M.W.J. Ferguson(eds.) Gray's Anatomy, 38th Ed. New York: Churchill Livingstone 1826-1827, 1995.

[11]. Panda SS, Bajpai M, Jana M, Baidya DK, Kumar R. Anderson-Hynes pyeloplasty with isthmotomy and lateropexy in horseshoe kidneys with pelviureteric junction obstruction in children. Indian J Urol 2014;30:161-3.

How to cite this article: Kapil Rampal, Devendra Prajapati, M eghna Sharma. Review of three Common Congenital Abnormalities of Kidney and their Clinical Perspective with an Elaboration on a rare case of Co-Occurrence of Horse Shoe Kidney , Unilateral Duplex Kidney And Aberrant Renal Vessel With Pelviureteric Junction Obstruction Of The Lower Moiety. Int J Intg M ed Sci 2016;3(7):365-368. DOI: 10.16965/ijims.2016.140 